\title{
Overview of the Efficient Tehnologies for Power Generation Based on Coal
}

\author{
Enver AGIĆ*, Damir ŠLJIVAC, Branka NAKOMČIĆ-SMARAGDAKIS
}

\begin{abstract}
This paper gives an overview of effective technologies for coal-based electricity generation. The introductory chapter presents the development of efficient electricity production from the end of the nineteenth century to the present, and the emphasis is placed on the examination of modern efficient technologies for electricity production in the 21th century with a detailed comparison of hard coal combustion (PCC) and fluidised bed combustion (CFCB) technologies. Pollutants such as carbon monoxide (CO), sulfur oxides $\left(\mathrm{SO}_{x}\right)$ and nitrogen oxides $\left(\mathrm{NO}_{x}\right)$ occur during the process of coal combustion. $\mathrm{SO}_{2}$ and $\mathrm{NO}_{x}$ cause the acid rain and $\mathrm{CO}_{2}$ gas is the most responsible for the greenhouse effect. With using the new fire-resistant steels based on nickel, the TPP with advanced ultra-supercritical steam parameters (A-USC) with $t$ $=700{ }^{\circ} \mathrm{C}$ and working $p=350$ bar are expected, and also, this will increase the efficiency above $50 \%$. In this paper, this and other emerging technologies have been presented as well as the comparison of their characteristics.
\end{abstract}

Keywords: characteristic comparison; coal; efficient technologies; environmental pollution; optimization; power plant lifecycle

\section{INTRODUCTION - HISTORICAL EFFICIENCY DEVELOPMENT OF TECHNOLOGIES FOR ELECTRICITY PRODUCTION BASED ON COAL}

A broad overview of historical parameters achieved in the consumption, emmision and efficiency in the electricity production, i.e. power generation is presented in Tab. 1.

Table 1 Broad overview of historical comsumption, emmision and efficiency parameters in power generation

\begin{tabular}{|c|c|c|c|}
\hline Year & $\begin{array}{c}\text { Consumption } \\
\text { tce/ } 1 \mathrm{kWh}\end{array}$ & $\begin{array}{c}\text { Emisssion } \\
\mathrm{CO}_{2} / \mathrm{kWh}\end{array}$ & $\begin{array}{c}\text { Efficiency } \\
\eta / \%\end{array}$ \\
\hline End of XIX century & 0,01230 & $37[1]$ & 1 \\
\hline $1900-1910$ & 0,00670 & 2,5 & 5 \\
\hline 1925 average & 0,00080 & 2,1 & $15[2]$ \\
\hline 1970 & 0,00028 & 0,76 & 43 \\
\hline 1992 & 0,00031 & 0,85 & 38,90 \\
\hline
\end{tabular}

Main remarks and historical achivements are presented as follows:

- Increasing the efficency was achieved using a steam turbine.

- In 1926, the plant "Klingenberg" in Berlin commissioned a turbogenerator with power of $80 \mathrm{MW}$, (then the largest in the world, fuel coal), reached the highest efficiency $27 \%$, consumption of 0,000045 tce $/ \mathrm{kWh}$ and $\mathrm{CO}_{2}$ emissions of $1,2 \mathrm{~kg} \mathrm{CO} / \mathrm{kWh}$.

- In 25 years, fuel consumption is reduced by more than two thirds [3].

- In the second half of the 90 s, an efficiency of $47 \%$ was achieved in the TPP Nordjyland in Denmark with supercritical steam parameters and coal.

- Brown coal and lignite plants have lower efficiency due to the nature of coal in relation to mineral coal (moisture content).

- In Germany, new energy blocks on lignite achieved a net efficiency with DTV of 42,3\% (Lippendorf, $2 \times 920$ $\mathrm{MW}, 260 \mathrm{bar} / 554{ }^{\circ} \mathrm{C} / 583^{\circ} \mathrm{C}$ ) and $45,2 \%$ (Niederaussem $\mathrm{K}, 950 \mathrm{MW}$-net, $260 \mathrm{bar} / 580{ }^{\circ} \mathrm{C} / 600{ }^{\circ} \mathrm{C}$, in operation in 2002 year) [4].

- Net efficiency greater than $43 \%$ is expected in the power plant Neurath (Germany) powered on the Rhine lignite with power of $2 \times 1120 \mathrm{MW}\left(272 \mathrm{bar} / 600^{\circ} \mathrm{C} / 605\right.$ $\left.{ }^{\circ} \mathrm{C}\right)[5]$.
- Similar energy efficiency results were achieved in new coal-fired power plants in Denmark, the US, Japan, China and South Korea [6].

Due to the environment, the question is whether the coal is compatible with sustainable development. Are the new measures taken to reduce consumption of fossil fuels and increasing the efficiency of energy transformation of coal into electricity appropriate? The new clean coal technologies are being developed without the growth of warming. As a large number of coal-fired power plants are at the end of their lifecycle, is it possible to achive clean coal-based electricity production by replacing them with new clean coal technologies?

This paper aims to present the overview of the new efficient and clean technologies in order to try to answer these questions.

\section{FUNDAMENTALS OF ENERGY EFFICIENCY}

Specific energy consumption is expressed in the relationship of fuel heat consumed for production of $1 \mathrm{kWh}$ of electricity and is the reciprocal value of the degree of power plant efficiency:

$$
q_{\mathrm{TE}}=\frac{1}{\eta_{\mathrm{TE}}}=\frac{3600 \mathrm{~kJ} / \mathrm{kWh}}{\eta_{\mathrm{TE}}} \cdot 100, \mathrm{~kJ} / \mathrm{kWh}
$$

Specific energy consumption is expressed as a specific fuel consumption $(\mathrm{kg})$ for producing $1 \mathrm{kWh}$ of electricity $(\mathrm{kg} / \mathrm{kWh}) . \eta$ is expressed at lower heating fuel value. Total (gross) and annual net (operating) $\eta$ differ. Overall $\eta$ is the total production of electricity in the generator divided by the heat consumption of fuel in the boiler of thermal power plant (TPP), and for the net $\eta$, electricity at the doorstep of the power plant is calculated (total minus the local TPP consumption). Annual $\eta$ is the annual production of electricity (gross or net) divided by the annual energy fuel consumption. The net $\eta$ coal plants can be defined by the expression [7]:

$\eta_{\mathrm{TE}}=\eta_{\mathrm{RC}} \cdot \eta_{\mathrm{t}} \cdot \eta_{\mathrm{g}} \cdot \eta_{\mathrm{k}} \cdot \eta_{\mathrm{s} . \mathrm{p}}$ 
where labels and guiding values $\eta$ for the steam temperature of $580{ }^{\circ} \mathrm{C}$ at the entrance of the modern turbine are:

- $\quad \eta_{\mathrm{RC}}=\eta_{\mathrm{C}} \cdot \eta_{\mathrm{ex}}=0,65 \cdot 0,94=0,61$ ili $61 \%$ - Rankine efficiency at $\eta_{\mathrm{C}}=65 \%$ and content of exergy in steam at $\approx 94 \%$;

- $\eta_{\mathrm{t}}=93 \%$ - efficiency of modern steam turbines;

- $\quad \eta_{\mathrm{g}}=98 \%$ - efficiency of modern electric generators;

- $\quad \eta_{\mathrm{k}}=91 \%$ - efficiency of modern boilers;

- $\eta_{\text {s.p. }}=93 \%$ - efficiency of auxiliary equipment of the TPP (own consumption approximately 7\%).

Net efficiency of modern coal plants by improving conventional technologies would be 47\% (61\%* 93\%* $98 \% * 91 \% * 93 \%)$. e.g. Danish power plants on coal dust "Nordjylland 3" of $400 \mathrm{MW}$, put into operation in 1998 with two of overheating and steam parameters: 290 bar / $580{ }^{\circ} \mathrm{C} / 580{ }^{\circ} \mathrm{C} / 580{ }^{\circ} \mathrm{C}$ [8] have such efficiency. Efficiency can further be increased by introducing new materials and improvement of thermal schemes by optimizing its components [9].

However, majority of existing coal power plants have lower efficiency (e.g. in Bosnia and Herzegovina brown coal or lignite are used, having a lower efficiency and technology from 1970s). Today's coal plants are in most cases 30-40 years old constructions, with subcritical steam parameters $\left(530{ }^{\circ} \mathrm{C}\right.$ to $540{ }^{\circ} \mathrm{C}$ and 140 bar to 180 bar), and degree of thermal efficiency of $36 \%$ - $39 \%$.

Unfinished project "Lukovo" Šugarje in Croatia [10] predicted efficiency over $43 \%$, while the last built German and Danish power plants on coal achieve a maximum efficiency of $47 \%$. The most recently constructed coal plants with ultra-supercritical steam parameters $\left(>600{ }^{\circ} \mathrm{C}\right.$ and $>300$ bar) provide efficiency levels over $50 \%$ [11].

\section{NEW EFFICIENTY COAL COMBUSTION TECHNOLOGIES}

Today, in the 21 century, special attention is devoted to the energy consumption in the developed countries. This is a first-rate issue in each country [12]. Relevant recommendations of the European Commission (document "Reference Document on Best Available Techniques for Large Combustion Plants", July 2006, Chapter 4, section 4.5.5. Thermal eficiency) are used to recommend the technologies and determine minimal efficiency of new coal power plant units. They are presented in Tab. 2.

Table 2 Relevant recommendations of the EC on net thermal efficiency of the best available techniques for large coal combustion technologies

\begin{tabular}{|c|c|c|}
\hline \multirow{3}{*}{ Lignite } & $\begin{array}{c}\text { Technology of coal } \\
\text { combustion }\end{array}$ & $\begin{array}{c}\text { Net efficiency } \\
\text { new units, } \%\end{array}$ \\
\cline { 2 - 3 } & PCC & $42-45 \%$ \\
\cline { 2 - 3 } & FBC & $>40 \%$ \\
\hline
\end{tabular}

Where: PCC - pulverised coal combustion, FBC - fluidized bed combustion and CFBC - circulating fluidized bed combustion.

Although the overview will focus on PCC, FBC and CFBC technologies, these are only a segment of advanced technologies for power generation from coal combustion and gasification where overall possible solutions are presented in Fig. 1.

Where abbreviations stands for:

- EFCC external combustion in combined cycle
- USC Ultra-super critical plants

- PCC pulverized coal combustion

- FBC fluidized bed combustion

- $\quad$ PFBC fluidized bed combustion under pressure

- $\quad$ CFBC circulating fluidized bed combustions

- P-CFBC circulating fluidized bed combustions under pressure

- $\quad$ IGCC integrated gas combined cycle.

While FBC and CFBC take place at atmospheric pressure in steam generator, the $\mathrm{PFBC}$ and $\mathrm{P}-\mathrm{CFBC}$ combustions take place at elevated pressure, which improves the characteristics and the overall efficiency.

Emerging IGCC (Integrated Gas Combined Cycle) is based on the PFBC which adds a carburator in which synthetic gas is generated. Heat from the gasification is used for steam production in steam turbine while the synthetic gas burns in a gas turbine. The plant has a very high degree of efficiency (57-59\%) [14].

Also, at the global level, significant investment and research efforts are put to increase technological feasibility and economic viability of using coal to generate electricity, with most attention focused upon reducing $\mathrm{CO}_{2}$ emissions. At present, the technology of separation and storage of $\mathrm{CO}_{2}$ from the combustion of fossil fuels is expensive, costing from $40 \mathrm{USD} / \mathrm{t} \mathrm{CO}_{2}$ to $60 \mathrm{USD} / \mathrm{t} \mathrm{CO}_{2}$ [15]. This gives a gain of about 3,5 USc/kWh to $5,5 \mathrm{USc} / \mathrm{kWh}$ on electricity prices, with average efficiencies of coal plants of $35 \%$.

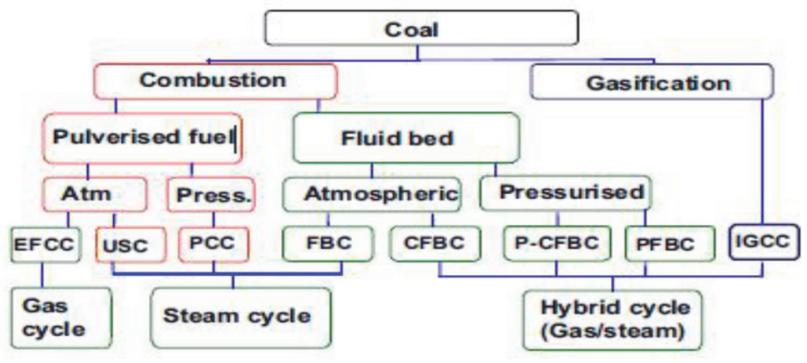

Figure 1 Advanced technologies for the coal combustion [13]

\subsection{The Pulverised Coal Combustion Technology - PCC}

The pulverised solid fuel (coal) combustion technology (PCC) is used by approximately $90 \%$ of all coal-fired boilers. Grinding and drying of coal in order to increase efficiency is becoming more common. The level of efficiency in the process of exploitation is significantly influenced by soiling, coal quality, steam presure and steam temperature. Efficiency is increased with raising rated (installed) power of the block and with greater availability, in case of optimal load. Additional measures to increase the efficiency are coal drying and use of waste heat from flue gases.

Supercritical parameters to achieve efficiency increase are used for blocks with a capacity greater than $400 \mathrm{MW}$. Power plants on coal with supercritical parameters can reach the energy efficiency over $42 \%$ depending on the quality of coal and the block size. For block-based combustion technology of pulverized coal (PC) it is hard to reach the net efficiency over $42 \%$, which can only be realized by using so-called ultra critical (USC) steam parameters (pressure 250-275 bar, fresh steam temperature $>585{ }^{\circ} \mathrm{C}$ ). These steam parameters require technical 
minimum of more than $370 \mathrm{MW}$. With the current state of technology for conventional PCC coal plants, the maximum achievable performance is about $46 \%$. This performance is achieved in subcritical and supercritical conditions (steam temperature of about $610^{\circ} \mathrm{C}$ instead of the current $540{ }^{\circ} \mathrm{C}$ ).

Table 3 High-efficiency PCC power plants

\begin{tabular}{|c|c|c|c|}
\hline Power plant & Rated power & Efficiency & Type \\
\hline Neurath (D) & $2 \times 1100 \mathrm{MW}$ & 43 & PCC \\
\hline Walsum (D) & $750 \mathrm{MW}$ & 43 & PCC \\
\hline Soštanj (SLO) & $600 \mathrm{MW}$ & 43 & PCC \\
\hline Ledvice (CZE) & $660 \mathrm{MW}$ & 42,5 & PCC \\
\hline Civitavecchia (ITA) & $3 \times 660 \mathrm{MW}$ & 45 & PCC \\
\hline Tušmice (CZE) & $4 \times 200 \mathrm{MW}$ & $37,82 \%$ & PCC \\
\hline
\end{tabular}

Development of PCC technology is focused on:

- increasing the thermal $\eta$ - by increasing steam

- parameter from the boiler/ on the entrance of the steam turbine,

- flexibility of the boiler operation at lower loads and,

- meeting the environmental demands (flue gas emissions).

Table 4 Reference list of blocks 200-660 MWe[16]

\begin{tabular}{|c|c|c|c|c|}
\hline $\begin{array}{c}\text { Boiler } \\
\text { supplier }\end{array}$ & $\begin{array}{c}\text { Foster } \\
\text { Wheeler }\end{array}$ & $\begin{array}{c}\text { Babcock \& } \\
\text { Wilcox }\end{array}$ & Alstom & Rafako \\
\hline Client & $\begin{array}{c}\text { Kiewit/Black } \\
\text { \& Veatch, } \\
\text { Bechtel, } \\
\text { Power Corp. }\end{array}$ & $\begin{array}{c}\text { WPS, PT } \\
\text { PLN }\end{array}$ & $\begin{array}{c}\text { Elektro- } \\
\text { wnia } \\
\text { Patnow II }\end{array}$ & $\begin{array}{c}\text { Polska Grupa } \\
\text { Energetyczna }\end{array}$ \\
\hline $\begin{array}{c}\text { Construct. } \\
\text { start }\end{array}$ & 2009,2006 & 2008,2006 & 2004 & 2009 \\
\hline Object & $\begin{array}{c}\text { Dallman \#4, } \\
\text { Springerville } \\
\# 3\end{array}$ & $\begin{array}{c}\text { Weston 4, } \\
\text { TanjugJati } \\
\text { B }\end{array}$ & $\begin{array}{c}\text { Patnow } \\
\text { blok 1 }\end{array}$ & Belchatow \\
\hline $\begin{array}{c}\text { Country } \\
\text { Rated } \\
\text { power/steam } \\
\text { production }\end{array}$ & $\begin{array}{c}\text { USA,USA } \\
\text { 400 Mwe, }\end{array}$ & $\begin{array}{c}\text { USA, } \\
\text { ndonezija }\end{array}$ & Polska & Polska \\
\hline $\begin{array}{c}\text { Primary } \\
\text { fuel }\end{array}$ & Coal,Coal & Coal,Coal & lignite & lignite \\
\hline
\end{tabular}

\begin{tabular}{|c|c|c|c|c|}
\hline $\begin{array}{c}\text { Boiler } \\
\text { supplier }\end{array}$ & Alstom & Alstom & Alstom & Siemens \\
\hline Client & $\begin{array}{c}\text { ŠKODA } \\
\text { Praha Invest }\end{array}$ & $\begin{array}{c}\text { Holding } \\
\text { HSE }\end{array}$ & ČEZ & \\
\hline $\begin{array}{c}\text { Construct. } \\
\text { start }\end{array}$ & 2016 & 2014 & 2016 & 2013 \\
\hline Object & Ledvice & Šštanj & Ledvice & Lünen \\
\hline Country & Czech & Slovenia & Czech & Germany \\
\hline $\begin{array}{c}\text { Rated } \\
\text { power/steam } \\
\text { production }\end{array}$ & $660 \mathrm{MWe}$ & $600 \mathrm{MW}$ & $660 \mathrm{MW}$ & $750 \mathrm{MW}$ \\
\hline $\begin{array}{c}\text { Primary } \\
\text { fuel }\end{array}$ & lignite & lignite & lignite & hard coal \\
\hline
\end{tabular}

PCC process is extremely complex and depends on several factors, because getting the boiler surfaces on the gas side dirty is not recommended for coal with high ash content or for problematic coal from the combustion point. PCC technology includes preliminary preparation of coal, grinding and drying the logs in dust outside the boiler in an installation in which a process of coal grinding and drying is conducted. Depending on the type of coal, the combustion takes place at temperatures between $1100{ }^{\circ} \mathrm{C}$ and $1700{ }^{\circ} \mathrm{C}$. The process of making is the combination of two opposite processes: agglomeration i.e. deposition of un-burnt smaller airborne particles and abrasion i.e. wear layers deposited with large particles.

The main suppliers of PCC boilers are: Alstom, Babcock Power (BP), Babcock and Wilcox (B \& W), Babcock-Hitachi (BH), Foster Wheeler (FW), Hitachi Corp., Mitsui Babcock (MB ), Ishikawajima Harima Heavy Industries (IHI), Rafako, SAS, etc. The size and classification of the existing steam blocks suppliers, reference list of blocks built after 2004 is presented in Tab. 4.

Today, the rated power of a steam turbine with PCC technology is in the range of $50 \mathrm{MWe}$ to $1300 \mathrm{MWe}$. From the point of utilization of economies of scale, most of the new blocks have capacity of more than $300 \mathrm{MWe}$, and less than $700 \mathrm{MWe}$, because of the significant influence of such large blocks on power system in the case of failure or other unplanned downtime.

\subsection{The Fluized Bed Coal Combustion Technology - FBC}

Research and implementation of fluized bed solid fuel (coal) combustion (FBC) emerged as an alternative to boilers with combustion of pulverized coal (dust) in the chamber, looking for cheaper and more efficient solution for reducing sulphur-oxides $\left(\mathrm{SO}_{x}\right)$ from flue gases. The development of FBC started with Winkler patent for the gasification of lignite (1922)[17], used for different purposes since then. Over time the main FBC goal has evolved into a "clean energy for the future" [18].

The test plant with the bubble (stationary) fluidised bed started in US in 1965 with the aim of controlling $\mathrm{SO}_{2}$ emissions. To date, four generations of $\mathrm{FBC}$ have been developed and they belong to the clean coal technologies (CCT). FBC is known for its ability to burn substandard fuels with low calorific value, fuels with high ash content and high humidity. Other benefits are reduced emissions, re-use of non-hazardous by-products from the desulfurization (eg. Gypsum) and the possibility of applying this technology in already built facilities.

The fuel that makes $1-3 \%$ of the material layer mass, burns in a hot bed of inert material (quartz sand, ash, limestone/sorbent) due to flow-through of air from the bottom of the combustion chamber in a state of levitation and shows properties similar to liquid (state of fluidization) [19]. Fluidization occurs when the fluid flows arround particles of solid material in the opposite direction of gravity, and apparently reduces their weight. At the time of transition from hibernation to the fluidized state, the resistance force of gas passing through layer of particles is equal to the weight of particles in the layer. Since the fluid has mutually separated particles of layer, it can no longer hold shear force and begins to behave like a liquid. A layer of fine-grained solid material which has these characteristics is called a fluidized bed. High speed dispersion of fuel inserted in a large mass of inert material, intensive mixing of fuel, a large surface area for the exchange and transfer of heat through contact with the particle layers allow combustion of the fuel at a lower temperature $\left(760-900{ }^{\circ} \mathrm{C}\right)$ as compared to boilers with air cobustion. Lower teperature is resulting in a significant reduction in forming thermal $\mathrm{NO}_{x}$, while the effective retaining of the sulfur and halogen in the combustion chamber is achieved by introducing limestone or dolomite 
in layer. Combustion of solid fuel in a fluidized bed is a transition process between the combustion in the combustion layer and in the air. These are the newer technologies, flexible in terms of fuel use of different quality. A stable activity on the low power and significant reduction of pollutant emissions $\left(\mathrm{SO}_{2}\right.$ and $\left.\mathrm{NO}_{x}\right)$ are positive sides of this technology.

Depending on the regime of fluidization i.e. speed of flow-through gas through the layer, we differ [20]: stationary or bubbly fluidized bed (BFB) and circulating fluidized bed (CFB). Tab. 5 shows the comparative analysis of these two types of boilers.

Table 5 Comparative characteristics of boilers with stationary (bubble) (BFB) and circulating fluidized bed (CFB):

\begin{tabular}{|c|c|c|}
\hline Parameter & BFB & CFB \\
\hline Combustion temperature $/{ }^{\circ} \mathrm{C}$ & $760-870$ & $800-900$ \\
\hline Fluidizing velocity $/ \mathrm{m} / \mathrm{s}$ & $1-3$ & $3-10$ \\
\hline Middle steam parameters & & \\
\hline Steam flow $/ \mathrm{kg} / \mathrm{s}$ & $13-139$ & $12-360$ \\
\hline Steam temperature $/{ }^{\circ} \mathrm{C}$ & $150-543$ & $180-580$ \\
\hline Steam pressure $/ \mathrm{bar}$ & $10-160$ & $10-275$ \\
\hline
\end{tabular}

Boilers with CFB have an advantage in the field of higher power (over $100 \mathrm{MW}$ ) in burning low-active coals and in the terms of the sharp emission regulations. They are almost exclusively steamy, industrial, and they have been recently integrated in the electric power systems. The initiators of the development and expansion of the CFB technology are regulated market, regulations for the environmental protection, specificity of region and it is bound to the available fuel (its quantity and quality). Some constructed FB boilers:

a. BFB boiler Metso Power ACZ [21] for burning waste;

b. CFB boiler Alstom Sulcis, Italy (340 MWe steam parameters: 197 bar, $\left.565 / 580^{\circ} \mathrm{C}, 1026 \mathrm{t} / \mathrm{h}\right), 2006$;

c. CFB boiler Metso Power CZMIC, Manitowoc Public Utilities, Wisconsin, United States (160 MWth, 60 $\mathrm{kg} / \mathrm{s}, 103$ bar, $541{ }^{\circ} \mathrm{C}$ ), burns petroleum coke, brown coal, 2005;

d. Foster Wheeler Energy CFB boiler in Turow'u Poland $\left(3 \times 557 \mathrm{MWth}, 195 / 181 \mathrm{~kg} / \mathrm{s}, 170 / 39 \mathrm{bar}, 568 / 568{ }^{\circ} \mathrm{C}\right)$ fuel-lignite, 2003 to 2004 ;

e. Foster Wheeler supercritical [22] CFB boiler, Lagisza, Bedzin, Poland (996 MWth, 361/306 kg/s, 275/50 bar, 560/580 $\left.{ }^{\circ} \mathrm{C}\right), 2009$.

Today, boiler units for FBC have developed the rated power of typical PCC boiler. The FBC technology is based on the introduction of coal particles about $3 \mathrm{~mm}$ into the hot turbulent layer in which, from the bottom of the boiler, the air needed for combustion is developed. The amount of fuel in the layer is approximately $1 \%$ to $3 \%$ of the base material, and the remaining is ash, sand and sorbents, required to start the process. Due to the initiation of air the whole mixture becomes fluidized and abrasive bits of coal are added into the layer. Because of high combustion temperatures $\left(750{ }^{\circ} \mathrm{C}-950{ }^{\circ} \mathrm{C}\right)$ and a long period of stay in combustion zone, the particles of coal burn quickly, which gives a lower value of emissions of combustion products.

For combustion in the CFB boiler mixture of fuel, sand, ash, sorbate and air, which is initiated from the bottom of the firebox, the boiler achieves high speed, the particles are whole time in the flue gases.
The fluidized bed was maintained so that the flue gases from the combustion chamber are introduced into the cyclone (separator), where the larger unconsumed particles of layer (sand and ash) and fuel are separated from the flue gases, and then they are reintroduced i.e. recirculate fluidized bed. Because of the recirculation of materials the name of the technology is circulating fluidized bed. Depending on the size and speed of combustion, some fuel particles can be recirculated 10 to 50 times, and their time of stay in the boiler is a tenth of a second. For combustion technologies in the circulating fluidized bed (FBC), a net efficiency over $40 \%$ is required, which (along with the specified parameters of steam) is achievable in practice and proven on reference plants. The projected level of net efficiency with $\mathrm{FBC}$ technology is $40,82 \%$.

Fuel combustion in the CFB boiler gives lower emissions of $\mathrm{NO}_{x}$ compared to PCC technology, and higher emission levels of $\mathrm{N}_{2} \mathrm{O}$. $\mathrm{SO}_{2}$ emissions can be effectively and economically reduced directly by injection of sorbent (limestone) in the layer which upon reaction with sulfur from the flue gases drains away from the process together with the ash. Therefore, construction of chamber for desulphurisation of flue gases is not needed. The technology is suitable for low-calorie coal with a large amount of ash, which is difficult to translate in the pulverized coal and coals whose characteristics are subject to change. The technology is also suitable for the combustion of coal as the main fuel to whom the fuel of inferior quality is added, (eg. Scrap). Designers Supplier of equipment is Foster Wheeler and Alstom for Turow, and the power plant owner is PGE- Polska Group Energetyczna.

The main suppliers of CFBC boilers are: Alstom, Austrian Energy \& Environment, Babcock and Wilcox, Foster Wheeler, Metso. Overview of the blocks with athmosferic FB (BFB aor CFB) boiler of unit capacity above $150 \mathrm{MWe}$ is presented in Tab. 6 .

Benefits of technologies with wet limestone process are that it is cheap and avaliable in nature, a by-product (gypsum) has a market value, low consumption of ground limestone and a high degree of separation of $\mathrm{SO}_{x}$. Lack of technology is the low temperature of unsaturated wet flue gases (conditional use of materials flue-resistant acid), producing waste water, the higher the investment value complex equipment plants and use of materials resistant to acid, additional $\mathrm{CO}_{2}$ emissions because of the reaction of limestone and of $\mathrm{SO}_{2}$, greater surface area.

Emissions of carbon monoxide (CO) are for the PCC technology slightly lower. For PCC technology, building a plant for desulfuration by wet process is essential, which requires larger investments, more maintenance costs, larger required area for the plant construction.

Abrasive slurry and corrosive flue gases are the main reason for the application of special anti-corrosion protection and use of pumps resistant to abrasion and corrosion. For the block with CFBC boiler, it is possible to desulfurate in the boiler, upgrading the plant for desulfuration by wet process and so reduce the consumption of limestone. If the removal of the powder particles from the flue gases uses the electrofilter or bag filters, the emission values are around $30 \mathrm{mg} / \mathrm{Nm}^{3}$ for both technologies. 


\begin{tabular}{|c|c|c|c|c|c|c|c|}
\hline Company/ Power plant & Location & Supplier & Type & $\begin{array}{l}\text { Rated } \\
\text { power } \\
\text { MWe }\end{array}$ & $\begin{array}{c}\text { Cogen } \\
\text { eration } \\
/ \mathrm{kg} / \mathrm{h} \text { of } \\
\text { steam }\end{array}$ & Start & Fuel \\
\hline Tennessee Valley Authority & Paducah, KY & CE (1) & BFB & 160 & & & Brown coal 3,5\% sulphur \\
\hline $\begin{array}{l}\text { Texas New Mexico } \\
\text { Power Company }\end{array}$ & Bremond, Texas & $\begin{array}{c}\text { ABB-CE (1) CFB } \\
2 * 160 \\
\end{array}$ & CFB & $2 \times 160$ & & 1990 & $\begin{array}{c}\text { Designed for lignite, } \\
\text { burns even petroleum coke }\end{array}$ \\
\hline $\begin{array}{l}\text { Nova Scotia Power } \\
\text { Corporation }\end{array}$ & $\begin{array}{c}\text { Point Aconi, Nova } \\
\text { Scotia }\end{array}$ & Pyropower (2) & $\mathrm{CFB}$ & 180 & & 1993 & $\begin{array}{c}\text { Brown coal } 20 \% \text { of ash, } 0,3 \% \\
\text { chlore, petroleum coke, coal from } \\
\text { import }\end{array}$ \\
\hline $\begin{array}{c}\text { Electric Power } \\
\text { Development Corp }\end{array}$ & Takehara, Japan & Hitachi (BFB) & $\begin{array}{l}\text { BFB } \\
\text { BFB } \\
\end{array}$ & 340 & & 1995 & Brown coal from import \\
\hline Electricité de France, Gardanne & Provence, France & $\begin{array}{l}\text { GEC-Alsthom- } \\
\text { Stein (1) }\end{array}$ & $\mathrm{CFB}$ & 250 & & 1996 & $\begin{array}{c}\text { Brown coal with } 30 \% \text { ash, } 4 \% \\
\text { sulphur }\end{array}$ \\
\hline KEPCO & Tonghae, S. Korea & KHI/ABB-CE & CFB & 230 & & 1998 & Korean anthracite \\
\hline National Power Supply & Thatoom, Thailand & Pyropower (2) & CFB & $2 \times 150$ & & 1998 & $\begin{array}{l}\text { anthracite, brown coal and } \\
\text { biomass }\end{array}$ \\
\hline Turow Power Station & Silesia, Poland & Pyropower (2) & CFB & $3 \times 230$ & & $\begin{array}{l}1998- \\
2000\end{array}$ & $\begin{array}{c}\text { Brown coal } 23 \% \text { ash, } 44 \% \\
\text { humidity }\end{array}$ \\
\hline AES, Warrior Run & Cumberland, MD & ABB-CE (1) & CFB & 180 & 82 & 2000 & Brown coal \\
\hline First Energy, Bay Shore & Toledo, Ohio & Foster Wheeler & CFB & 155 & $\begin{array}{l}155 \mathrm{t} / \mathrm{h} \\
\mathrm{psig} \text { of } \\
\text { steam }\end{array}$ & 2001 & Petroleum coke \\
\hline Alholmens Kraft Oy & Finland & Kvaerner & CFB & 240 & & 2001 & Wood, peat and lignite \\
\hline $\begin{array}{l}\text { Poland's Electric Power } \\
\text { Industry }\end{array}$ & Zeran, Poland & Rafako & CFB & $\begin{array}{c}2 \times 450 \\
\mathrm{t} / \mathrm{h}\end{array}$ & & $\begin{array}{l}1995 \\
2001\end{array}$ & Coal \\
\hline JEA & Jacksonville, FL & Foster Wheeler & CFB & $2 \times 300$ & & 2002 & Brown coal, petroleum coke \\
\hline Tractabel Power, Red Hills & $\begin{array}{l}\text { Chester, } \\
\text { Mississippi }\end{array}$ & ABB-CE (1) & CFB & $2 \times 220$ & & 2002 & Lignite \\
\hline AES & $\begin{array}{c}\text { Guayama, Puerto } \\
\text { Rico }\end{array}$ & ALSTOM Power & CFB & $2 \times 250$ & 181 & 2002 & Brown coal from import \\
\hline Turow Power Station & Silesia, Poland & Foster Wheeler & CFB & $3 \times 260$ & & $\begin{array}{l}2002 \\
2004\end{array}$ & $\begin{array}{c}\text { Brown coal } 23 \% \text { ash, } 44 \% \\
\text { humidity }\end{array}$ \\
\hline Donbas Energo & Ukraine & Lurgi & CFB & 200 & & 2003 & $\begin{array}{c}\text { Anthracite, low-energy coal and } \\
\text { mud }\end{array}$ \\
\hline Reliant Energy & Seward, PA & ALSTOM Power & CFB & $2 \times 260$ & & 2004 & Low-energy coal \\
\hline East Kentucky Power Coop & $\begin{array}{l}\text { Maysville, } \\
\text { Kentucky }\end{array}$ & ALSTOM Power & CFB & 268 & & 2004 & $\begin{array}{l}\text { Unwashed, Brown coal with a } \\
\text { lot of sulphit }\end{array}$ \\
\hline ENEL Sulcis & Sardinia & ALSTOM Power & CFB & 220 & 858 & 2004 & Various coals \\
\hline Taiheyo Cement & Shikoku, Japan & Foster Wheeler & CFB & 168 & & 2005 & Brown coal \\
\hline Baima & Sichuan, PRC & ALSTOM Power & CFB & 300 & & 2006 & $\begin{array}{c}\text { Anthracite } \begin{array}{l}35 \% \text { ash and 3,5\% } \\
\text { sulphit }\end{array} \\
\end{array}$ \\
\hline Kaiyun Power, Units $1 \& 2$ & Yunnan, PRC & ALSTOM Power & CFB & $2 \times 300$ & & 2007 & Lignite \\
\hline Dong Fang Boiler Group & $\begin{array}{l}\text { Baima, Sichuan } \\
\text { Province }\end{array}$ & ALSTOM Power & CFB & $2 \times 300$ & & 2008 & Brown coal \\
\hline Shanghai Boiler Works & Yunnan, PRC & ALSTOM Power & CFB & $2 \times 300$ & & 2008 & Lignite \\
\hline PEK & Lagisza, Poland & $\begin{array}{l}\text { Foster Wheeler, } \\
\text { Energia Oy }\end{array}$ & CFB & $460(3)$ & & 2008 & $\begin{array}{c}\text { Brown coal } 12 \% \text { humidity and } \\
23 \% \text { ash }\end{array}$ \\
\hline CLECO,Rodemacher \#3 & Boyce,Louisiana & Foster Wheeler & $\mathrm{CFB}$ & $2 \times 300$ & & 2009 & $\begin{array}{c}\text { Petroleum coke and biomass if } \\
\text { needed }\end{array}$ \\
\hline $\begin{array}{c}\text { East Kentucky Power Coop, } \\
\text { Spurlock \# } \\
\end{array}$ & $\begin{array}{l}\text { Maysville, } \\
\text { Kentucky }\end{array}$ & ALSTOM Power & CFB & 278 & & 2009 & $\begin{array}{c}\text { Unwashed, Brown coal with a lot } \\
\text { of sulphit }\end{array}$ \\
\hline TXU, Sandow \#5 & \begin{tabular}{|l|} 
Milam Co., Texas \\
\end{tabular} & Foster Wheeler & CFB & $2 \times 300$ & & 2010 & Lignite \\
\hline $\begin{array}{c}\text { Easti Kentucky Power Coop, } \\
\text { Smith\# }\end{array}$ & $\begin{array}{l}\text { Winchester, } \\
\text { Kentucky }\end{array}$ & ALSTOM Power & $\mathrm{CFB}$ & 278 & & & $\begin{array}{l}\text { Unwashed, Brown coal with a lot } \\
\text { of sulphit }\end{array}$ \\
\hline
\end{tabular}

(1) Now ALSTOM Power (2) Now Foster Wheeler (3) Cycle with supercritical parameters

\subsection{Research Projects}

Various energy technologies that will enable greater utilization of coal energy are being developed. Available technologies based on coal, today have reached $43-45 \%$ efficiency compared to the world average of $28-30 \%$, the specific $\mathrm{CO}_{2}$ emission of $730-930 \mathrm{~g} \quad \mathrm{CO}_{2} / \mathrm{kWh}$, as compared to the world average from $1.100 \mathrm{~g} \mathrm{CO}_{2} / \mathrm{kWh}$ to $1400 \mathrm{~g} \mathrm{CO}_{2} / \mathrm{kWh}$ with an appropriate reduction in specific fuel consumption. Reached steam temperatures and optimization of plant components, have enabled efficiency of TPP on stone coal to $47 \%$ and TPP on lignite to $45 \%$.

A further increase in the efficiency of "classic" coal fired thermal power plants is only possible by increasing the temperature of steam up to $700{ }^{\circ} \mathrm{C}$ (Europe) or up to
$760{ }^{\circ} \mathrm{C}$ (The USA). It is possible only by the development of new fire-resistant steel with large enough creep strength at such high temperatures. That is why the development programs are realized in the United States, Japan and the $\mathrm{EU}[23]$.

By the development of new fire-resistant steels based on nickel, thermal power plants with these advanced ultrasupercritical steam parameters (USC) with operating temeperature of $700{ }^{\circ} \mathrm{C}$ and pressure over 350 bar will have increased efficiency above $50 \%$.

According to the European project AD700 (Advanced $700{ }^{\circ} \mathrm{C}$ Pulverzed Coal-fired Power Plant), usage of alloyed steels (Super Alloy) on the basis of nickel is needed, which would use fresh steam pressure of approximately 375 bar and the temperatures of $700{ }^{\circ} \mathrm{C}$ to 
$720{ }^{\circ} \mathrm{C}$ but it needs to have adequate tensile strength and the yield strength during the ongoing 100.000 operating hours of work. Super alloy should have a yield strength of about $100 \mathrm{~N} / \mathrm{mm}^{2}$ at $750{ }^{\circ} \mathrm{C}$. The material, a candidate for the aforementioned conditions of steam temperature between $620{ }^{\circ} \mathrm{C}$ and $720{ }^{\circ} \mathrm{C}$ is the alloy Inconel 617 (NiCr23Co12Mo).

Achieving such a high initial steam parameters would enable thermal efficiency of 52 to $54,5 \%$, depending on the application of one or two overheating secondary steam.

Large companies on EU electricity market realize the European program COMETES 700, and it is implemented in more power plants in the EU. On the specific elements of the boiler (superheaters and intermediate superheaters steam collectors, pipelines), parts are made of materials that will be evaluated for their durability bed (creeping) and high temperature corrosion in the real conditions of the atmosphere gas in the boiler. Primarily, this applies to the austenitic steel and materials based on nickel. The predrying lignite with deducted steam turbine with a lowpressure (low temperature heat) is proposed.

There are two procedures for external dry lignite which are in the development: mechanical dewatering and thermal drying in a stationary fluidized bed with steam.
The heat of condensation (evaporation), the heating steam and Brid's steam coal are used. By combination of such advantageous conditions, it is possible to increase efficiency for extra 5\% when using the coal with moisture content of $50 \%$.

Another way of reducing specific $\mathrm{CO}_{2}$ emissions at TPP on coal dust is a combined combustion of coal and biomass (Effects of co-firing), by adding the biomass carbon in the amount of $10 \%$ to $20 \%$. Calculations and experiences show: with net efficiency of $40 \%$ for each addition of biomass of $10 \%$, reduction of the specific $\mathrm{CO}_{2}$ emissions is $56 \mathrm{~g} / \mathrm{kWh}$ [24].

PFBC plant efficiency is above $42 \%$ (HHV). The results show that the second generation of PFBC thermal units has as high efficiency as $46 \%$ (HHV). PFBC plant development aims achieving the efficiency of approximately $54 \%$, and up to $70 \%$ reduction in $\mathrm{NO}_{x}$ and $\mathrm{SO}_{x}$, and reduction of $\mathrm{CO}_{2}$ emission.

Lack of CFBC technology is higher consumption of limestone, a critical place is the exit of flue gases from the combustion chamber where flue gases are changing direction. The pipes in this part of the boiler are protected by the masonry walls, protected by cyclone and by the drain of hard particles back into the combustion chamber.

Table 7 Comparison of characteristics of combustion technology PCC and CFBC

\begin{tabular}{|c|c|c|c|}
\hline & Characteristics & PCC & CFBC \\
\hline \multirow{4}{*}{ FUEL CHARACTERISTICS } & a) the sensitivity of the quality of coal & - larger & + smaller \\
\hline & $\begin{array}{l}\text { b) the possibility of combustion } \\
\text { problematic coals }\end{array}$ & - no & + yes \\
\hline & $\begin{array}{l}\text { c) requirements by granulation of fuel for } \\
\text { distribution in boiler }\end{array}$ & $\begin{array}{l}\text { extremely accurately } \\
\text { specified }\end{array}$ & $\begin{array}{l}+ \text { accurately } \\
\text { specified }\end{array}$ \\
\hline & d) mixing & & + the best \\
\hline \multirow[t]{8}{*}{ TECHNICALCHARACTERISTICS } & a) technical minimum & & + low \\
\hline & b) range of block rated power & $\begin{array}{c}+ \text { wide } \\
(300 \div 800 \mathrm{MWe})\end{array}$ & $\begin{array}{c}- \text { narrow } \\
\text { (to } 460 \mathrm{MWe} \text { ) }\end{array}$ \\
\hline & c) gradient of load changes & + high & - lower \\
\hline & d) Availability & $>90 \%$ & $>90 \%$ \\
\hline & e) time for cold start & + shorter & - longer \\
\hline & f) additional power & - larger (BFCB) & - larger (fan blower) \\
\hline & g) the complexity of the plant & $\begin{array}{l}\text { - larger(mills,burners,FGD, } \\
\ldots \text {...) }\end{array}$ & + smaller \\
\hline & h) floor area of building blocks & - larger & + smaller \\
\hline \multirow[t]{10}{*}{ ENVIRONMENTAL CHARACTERISTICS } & a) emission values of $\mathrm{NO}_{x}$ - & higher values of $\mathrm{NO}_{x}$ & + lower \\
\hline & b) emission values of $\mathrm{CO}$ & 0 & lower \\
\hline & c) injection process $\mathrm{NH}_{3}$ for $\mathrm{SNCR}$ & 0 & $\begin{array}{l}+ \text { optimization of } \\
\text { temperature }\end{array}$ \\
\hline & $\begin{array}{l}\text { d) desulphurization in the combustion } \\
\text { chamber }\end{array}$ & no & yes \\
\hline & $\begin{array}{l}\text { e) temperature control in the combustion } \\
\text { chamber }\end{array}$ & 0 & the best \\
\hline & f) quantity of products desulphurisation & smaller & arger \\
\hline & g) use of products & application / use & conditional use \\
\hline & h) waste water from FGD & - requiring treatment & 0 \\
\hline & i) solid waste and waste water & $\begin{array}{c}+ \text { smaller } \\
- \text { water must be treated }\end{array}$ & $\begin{array}{l}- \text { larger } \\
+ \text { none }\end{array}$ \\
\hline & $\begin{array}{l}\text { j) use of flying ash and desulphuration } \\
\text { products }\end{array}$ & +larger & - smaller \\
\hline \multirow[t]{3}{*}{ ECONOMICAL ASPECTS } & a) investment costs & - higher* & + lower \\
\hline & b) operational costs & $\begin{array}{c}\text { - might be high } \\
\text { (mills, installations, ...) }\end{array}$ & $\begin{array}{l}- \text { might be high } \\
\text { (erosion, material } \\
\text { fatigue, ...) }\end{array}$ \\
\hline & c) electricity prices & - less competitive & + competitive \\
\hline
\end{tabular}

*) Include cost of catalyst for the separation of $\mathrm{NO} x$ from flue gases. 


\subsection{Comparison of Combustion Technologies}

Finally, an overview comparison of different characteristics of PCC and CFBD combustion technologies has been made and presented in Tab. 7 .

The advantages of using CFBC technology include:

- investment, operating costs and electricity prices,

- a wide range of fuel flexibility and the fuel consumption,

- stable efficiency on partial loads,

- effective cleaning of flue gases is only in the boiler,

- waste water does not have the facility for desulphurization,

- technical minimum (without reserve fuel),

- flexibility of action depending on the load.

From the standpoint of the degree of development, a great progress has been made with $\mathrm{CFBC}$, as a stand-alone technology. Fuel for these types of boilers is coal, lignite, biomass and a mixture of coal and biomass. In CFB combustion plants, a higher degree of combustion efficiency is achieved in the combustion chamber than in $\mathrm{BFB}$, more than $99 \%$. In terms of low-temperature combustion, effective binding reaction is conducted with $\mathrm{SO}_{x}$ particles limestone- $\mathrm{CaCO}_{3}$, lime $(\mathrm{CaO})$, and produced $\mathrm{CaSO}_{4}$, which is guided by the ashes from the boiler.

At relatively low temperature, in the combustion chamber, a smaller quantity of nitrogen oxides $\left(\mathrm{NO}_{x}\right)$ is formed, which is important for the environment. Efficiency of thermal power plants with FCB combustion of coal is similar to conventional PCC ones. The experience of the previous two thermal power plants with the CFB-boilers and supercritical parameters, Foster Wheeler will use as the basis for developing a set of such blocks with the supercritical steam parameters of 800 Mwe [25].

Operating expenses of CFBC technology are lower than in the PCC. Fuel supply in the combustion chamber is simple, fuel is only crushed, flue gas cleaning does not require additional installations (desulfuration is in the boiler). Maintenance costs for PCC boilers are higher for plant and for cleaning flue gases but for CFBC boilers these costs may be higher due to erosion and fatigue. The investment value of blocks with PCC boilers is higher than for CFBC boilers, because of the additional facililties for cleaning flue gases. Due to lower construction costs and operating costs, CFBC boiler technology is more competitive than PCC technology. Various studies compare these two technologies and state a difference of approx. 7\%. Technology with CFBC boilers with subcritical parameters has certain economic advantages over the technology of PCC boilers.

The cost of technology with CFBC boilers and PCC is conditioned by current scale on the market, and the difference is relatively small. The difference is greater in the example of coal with the high sulfur content. Block boiler of PCC requires more space to build.

Table 8 The cost comaprison for PCC over CFBC technology

\begin{tabular}{|c|c|c|}
\hline TEHNOLOGY & PCC & CFBC \\
\hline Fuel / \% & $\mathbf{1 0 0}$ & $\mathbf{1 0 2}$ \\
\hline Efficiency block to TPP* & Might be larger to $0,5 \%$ & \\
\hline Construction work / \% & $\mathbf{1 0 0}$ & $\mathbf{9 0}$ \\
\hline Investments / \% & $\mathbf{1 0 0}$ & $\mathbf{9 0}$ \\
\hline $\begin{array}{c}\text { Operational and maintenance } \\
\text { costs / } \%\end{array}$ & $\mathbf{1 0 0}$ & $\mathbf{9 0}$ \\
\hline The price of electricity / \% & $\mathbf{1 0 0}$ & $\mathbf{9 5}$ \\
\hline
\end{tabular}

* - Refers to the lower calorific value
A comparison of costs for PPC over CFBC is presented in Tab. 8.

\section{CONCLUSION}

The consumers will certainly reduce energy consumption which will result in reduction of the environmental pollution [26]. Although the world is committed to reducing $\mathrm{CO} 2$ emissions in the next fifty years, its emissions will still be significant [27].

Since its introduction and use started in the early twentieth century, PCC technology has maintained a dominant role in the production of electricity from coal, and currently represents more than $90 \%$ of installed capacities in the world. Grinding and drying of coal in order to increase the efficiency is becoming more common. At the level of efficiency in the process of exploitation, it significantly influences soiling, coal quality, pressure and temperature of steam. Efficiency and availability are increasing with economies of scale, or as units with higher power, in case of the optimal load [28].

In addition to increasing the efficiency of coal drying and utilization of waste heat from flue gases, supercritical parameters for increase in efficiency are used for blocks capacity greater than $400 \mathrm{MW}$, depending on the quality of coal and the block size.

CFBC is the simplest technology for coal combustion, due to the construction of devices for the introduction of fuel as a combustion chamber; a flue gas cleaning process begins in the combustion chamber, represents the best compromise of efficiency and ease of installation, environmental requirements and economic indicators. The biggest advantage of this technology is flue gas desulphurization in the boiler combustion chamber; it is possible to achieve the required emission of $\mathrm{SO}_{2}$ in flue gas of $150 \mathrm{mg} / \mathrm{Nm}^{3}$. With supercritical parameters and a steam turbine it is possible to increase the degree of efficiency of the block to $0,4 \%$, additional refrigerator of flue gases from new power plants is often built and increases energy efficiency by $0,6 \%$ and enables the use of a cooling tower for flue gas.

The technology of production of electricity from fossil fuels with zero emission of $\mathrm{CO}_{2}$ in atmosphere has not been developed yet to the level of commercial viability, but its realization can be expected in the next decade. Advances in the development of clean coal technologies should be taken into account in strategic planning capacity expansion in the power system, because relying on various primary energy sources, partly on coal, can ensure long-term reliability of electricity supply.

Newer CFB boilers are able to burn up to $20 \%$ biomass with little change in the boiler design. Addition of limestone in CFB boiler has the unwanted side effect of applying for the production of a much larger quantity of solid waste unsuitable for use as a replacement for cement. This is in contrast to the steady sales of fly ash and gypsum, produced by PCC boiler with wet FGD.

Fluidized bed combustion is gaining more than ever a ground among traditional ways of combustion due to high fuel flexibility. To conclude, a CFBC technology compared to PCC has: 
- $\quad$ CFBC has higher boiler efficiency due to the lower temperature exhaust flue gases and lower energy content paramount;

- CFBC boiler is more expensive (more complicated additional equipment: cyclones, fans of high pressure, fluidized bed, container limestone, preparation and transport of dry ash system by cooling water);

- $\quad \mathrm{CFBC}$ has greater risk of erosion of hard bits of ash than PCC;

- $\quad$ CFBC has higher net electricity consumption (greater consumption of air fan and induced draft fan, especially in partial load);

- $\quad$ CFBC is less flexibile to load changes (due to the heat accumulated in the circulation mass that is high; this causes worse conditions for the provision of primary and secondary control of frequency).

- $\quad$ CFBC requires better trained staff (due to different types of boilers and different technology than PCC).

- $\quad$ CFBC has greater flexibility in terms of different characteristics of energy (coal fluctuation of pits and mines, etc.).

- $\quad \mathrm{CFBC}$ has greater sensitivity to maintenance (internal components of the boiler exposed to extreme erosion)

- $\quad$ CFBC has less flexibility in terms of the diagram start (cold start for a long time: 7-8 h)

- $\mathrm{CFBC}$ power plants have lower availability due to complex maintenance.

The advantage of CFBC (to avoid flue gas desulphurization) is lost in case of a larger sulfur content in coal; then it is necessary to incorporate an additional plant for desulphurisation (NID system is semi-dry method - cheaper than wet); slag and waste as combustion products cannot be used in construction or other purposes (contaminated with ash and ammonia). The risk is in nonpermissible limit values for emissions with $\mathrm{CFB}$ technology (need additional installation of plants for flue gas desulphurization (FGD) and denitrification $\mathrm{DeNO}_{x}$ ). Both technologies can guarantee more than adequate reliability and availability.

\section{REFERENCES}

[1] Schilling, H. D. (2005). How did the efficiency of coal-fired power stations, and what can be expected in the future? The efficiency of coal-fired power stations, 1-8.

[2] Baude, V. Kraftwerksbauer sind Effizienz-Revolutionäre Siemens - Standpunkt, 2/96, 24.

[3] Baude, V. Kraftwerksbauer sind Effizienz-Revolutionäre Siemens - Standpunkt, 2/96, 26.

[4] Power Clean, T. N. (2004). Fossil Fuel Power Generation State-of-the-Art. P.T. Network.

[5] Elsen, R. \& Fleischmann, M. (2008). Lignite power Neurath $\mathrm{F}$ and $\mathrm{G}$ set new benchmarks. Modern Power Systems, 28(6), 2.

[6] Hg. Bundesministerium für Wirtschaft und Technologie (BMWi). 2009. Empfehlungen des COORETEC-Beirates zur Förderung von Forschung und Entwicklung $\mathrm{CO}_{2}-$ emissionsarmer Kraftwerkstechnologien und $\mathrm{CO}_{2}-$ Abscheide- und Speichertechnologien. Retrieved from: bmwi.de/Redaktion/DE/Publikationen/Energie/6energieforschungsprogramm-derbundesregierung.pdf?_blob=publicationFile \&v $=12$

[7] Mihahajlov, J. (1965). Termoelektrane projektiranje $i$ izgradnja. Zagreb, Croatia: Tehnička knjiga.
[8] The National Coal Council. (2006). Coal: America's Energy Future. Retrieved from:

nationalcoalcouncil.org/Documents/NCC_Report_Vol2.pdf

[9] Ugovor o uspostavi Energetske zajednice. (2005). Službeni glasnik BiH - Međunarodni ugovori, 09/06, čl. 16.

[10] Oštrić, Z. (2012). Termoelektrana Plomin C i strategija energetskog razvoja. Magazin, Heinrich Böll Stiftung za jugoistočnu Evropu - Ured za Bosnu i Hercegovinu, 2012(8), 22.

[11] Agić, E., Šljivac, D., \& Topić, D. (2012). The possibilities of increasing the energy efficiency in the city of Tuzla. Technical Gazette, 19(1), 131-139.

[12] Parliamentary Office of Science and Technology. (2005). Cleaner Coal (Number 253). Retrieved from: parliament.uk/globalassets/documents/post/postpn253.pdf

[13] Laković, M., et al. (2015). Kotlovi za sagorijevanje goriva u fluidizovanom sloju. Tehnika, 70(4), 625-630. https://doi.org/10.5937/tehnika1504625L

[14] Bogdan, Ž., Avdaković, S. A., Dokmanović, V., \& Merić, J. (2007). Tehnologije čistog ugljena u strategiji razvoja elektroenergetskog sustava. Journal of Energy: Energija, $56(4), 416$.

[15] Australian Uranium Association. (2006). Clean Coal Technologies. Retrieved from: uic.com.au/nip83.htm.

[16] Idejni projekt TE Banovići, Knjiga: A Osnovne karakteristike bloka. (2011). IBE d.d. Ljubljana, Br. svezka: TBANB1-3S/01, 5.1- 6/28

[17] Koornneef, J, Jungiger, M, \& Faaij, A. P. C. (2007). Development of FBC- An overviev of trends, perfomance and cost. Progress in Energy and Combustion Science, 33(1), 19-55. https://doi.org/10.1016/j.pecs.2006.07.001

[18] Leckner, B. (1998). Fluidized bed combustion: mixing and pollutant limitation. Progress in Energy and Combustion Science, 24(1), 31-61. https://doi.org/10.1016/S0360-1285(97)00021-X

[19] Mladenović, M. R. (2013). Istraživanje termomehaničkih procesa prilikom razgradnje tečnih goriva velikih gustina $u$ fluidizovanom sloju. Doctoral dissertation, University of Belgrade, Belgrade, Serbia. Retrieved from: core.ac.uk/download/pdf/197932567.pdf

[20] Koornneef, J., Jungiger, M., \& Faaij, A. P. C. (2007). Development of FBC- An overviev of trends, perfomance and cost. Progress in Energy and Combustion Science, 33(1), 19-55. https://doi.org/10.1016/j.pecs.2006.07.001

[21] Johnsson, F. (2007). Fluidized Bed Combustion for Clean Energy. The 12th International Conference on Fluidization New Horizons in Fluidization Engineering: Engineering Conferences International. Vancouver, Canada. Retrieved from: http://dc.engcon_ntl.org/uidization xii/5

[22] Laković, M., et al. (2015). Kotlovi za sagorijevanje goriva u fluidizovanom sloju. Tehnika, 70(4), 628. https://doi.org/10.5937/tehnika1504625L

[23] Vanstone, R. W. (2000). Advanced $\left(700^{\circ} \mathrm{C}\right)$ Pulverised Fuel Power Plant. Proc., Parsons 2000, Advanced Materials for 21 Century Turbines and Power Plant, 91-96. IOM Communications Ltd, London

[24] Izvještaj o kosagorijevanju otpadne drvne biomase i uglja na bloku 5 (110 MW) u TE Kakanj. (2011).

[25] Garafulić, E. \& Klarin, B. (2013). Acceptable concept of carbon dioxide storage. Technical Gazette, 20(1), 161.

[26] Lahidji, R., Michalski, W., \& Stevens, B. (1999). The Long term Future for Energy: An Assessment of Key Trends and Challenges. Energy: The Next Fifty Years, OECD.

[27] OECD/IEA. (2015). Energy Climateand Change World Energy Outlook Special Report. Retrieved from: iea.org/reports/energy-and-climate-change.

[28] Kaplan, S. (2008). Power Plants: Characteristics and Costs. UK: Nova Science Publishers. 


\section{Contact information:}

\section{Enver AGIĆ}

(Corresponding author)

The authorized court expert for electrical engineering,

Tuzla, Ul. ARBiH 19/IV/15, 75000 Tuzla, Bosnia \& Herzegovina

E-mail: agabiem@bih.net.ba

\section{Damir SLJIVAC}

Faculty of Electrical Engineering, University of J. J. Strossmayera in Osijek,

Kneza Trpimira 28, 31000 Osijek, Croatia

E-mail: damir.sljivac@etfos.hr

\section{Branka NAKOMČC-SMARAGDAKIS}

Faculty of Engineering, University of Novi Sad,

Trg Dositeja Obradovića 6, 21000 Novi Sad, Serbia

E-mail: nakomcic@uns.ac.rs 